\title{
Karyotypic characterization of Prochilodus mariae, Semaprochilodus kneri and S. laticeps (Teleostei: Prochilodontidae) from Caicara del Orinoco, Venezuela
}

\author{
Claudio Oliveira*, Mauro Nirchio**, Ángel Granado*** and Sara Levy**
}

Fish of the family Prochilodontidae are considered one of the most important components of commercial and subsistence fishery in freshwater environments in South America. This family consists of 21 species and three genera. In the present study, the karyotypes of Prochilodus mariae, Semaprochilodus kneri, and S. laticeps from Caicara del Orinoco, Bolivar State, Venezuela were studied. The species $P$. mariae, $S$. kneri and $S$. laticeps exhibited $2 \mathrm{n}=54$ chromosomes ( 40 metacentric and 14 submetacentric), a single chromosome pair with nucleolus organizer regions, and a large amount of heterochromatin found at centromeric and pericentromeric positions in almost all chromosomes. The P. mariae specimens studied displayed 0 to 3 supernumerary microchromosomes. The data obtained here confirm the conservative nature of the chromosome number and morphology of Prochilodontidae and reinforce the hypothesis that small structural chromosome rearrangements were the main cause of the karyotypic diversification seen in this group.

Os peixes da família Prochilodontidae são considerados um dos componentes mais importantes da pesca comercial e de subsistência em ambientes de água doce na América do Sul. Essa família compreende 21 espécies e três gêneros. No presente estudo foram analisados os cariótipos de Prochilodus mariae, Semaprochilodus kneri e S. laticeps provenientes de Caicara del Orinoco, Estado Bolivar, Venezuela. As espécies P. mariae, S. kneri e S. laticeps apresentaram 2n=54 cromossomos (40 metacêntricos e 14 submetacêntricos), um único par de cromossomos com regiões organizadoras de nucléolo e uma grande quantidade de heterocromatina em posição centromérica e pericentromérica de quase todos os cromossomos. Os espécimes estudados de $P$. mariae apresentaram de 0 a 3 microcromossomos supranumerários. Os dados obtidos aqui confirmam a natureza conservada do número e da morfologia cromossômica dos Prochilodontidae e reforçam a hipótese de que pequenos rearranjos estruturais foram os principais eventos fixados na diversificação cariotípica do grupo.

Key words: karyotype, C-band, NOR banding, chromossome evolution, Characiformes.

\section{Introduction}

Fish of the family Prochilodontidae are considered one of the most important components of commercial and subsistence fishery in freshwater environments in South America, with the exception of Chile, where these species are not found (Lowe-McConnell, 1975; Goulding, 1981; Vari, 1983). Castro \& Vari (in press) showed that this family comprises 21 species distributed in three genera: Ichthyoelephas (2 species), Prochilodus (13 species), and Semaprochilodus (6 species). In Venezuela, this family is represented by two genera and four species: $P$. reticulatus, $P$. mariae, $S$. kneri, and S. laticeps. The first species is found only in the Maracaibo Basin, while the other three are found in the Orinoco Basin.

Preliminary cytogenetic studies showed that Prochilodus lineatus (= Prochilodus scrofa) from the Mogi-Guaçu River, Brazil, exhibited $2 n=54$ chromosomes and zero to five supernumerary microchromosomes (Pauls \& Bertollo, 1983). These supernumerary microchromosomes have been widely studied under different methodologies including populational distribution, molecular constitution, meiotic behavior, and inheritance model (Oliveira et al., 1997; Dias et al., 1998;

\footnotetext{
*Departamento de Morfologia, Instituto de Biociências, Universidade Estadual Paulista, 18618-000 Botucatu, SP, Brazil. e-mail: claudio@ibb.unesp.br

**Escuela de Ciencias Aplicadas del Mar, Universidad de Oriente, Isla de Margarita, Venezuela. Apartado Postal 174. e-mail: nirchio@cantv.net

***Instituto Limnológico, Universidad de Oriente, Caicara del Orinoco, Estado Bolívar, Venezuela. e-mail: limnologico@cantv.net
} 
Cavallaro et al., 2000; Maistro et al., 2000; Jesus et al., 2003). Additional studies in the genus Prochilodus showed that eight species also had $2 \mathrm{n}=54$ chromosomes and that the species $P$. brevis ( $=$ P. cearensis) had zero to two supernumerary microchromosomes with characteristics similar to those found in the supernumerary chromosomes of $P$. lineatus (Pauls \& Bertollo, 1990). Cytogenetic studies conducted in species of the genus Semaprochilodus showed that S. insignis and S. taenirus, from the Negro River had $2 \mathrm{n}=54$ chromosomes (Feldberg et al., 1987). Additionally, the species $S$. taeniurus showed a putative ZZ/ZW sex chromosome system (Feldberg et al., 1987). In the present study, the karyotypes of Prochilodus mariae, Semaprochilodus kneri, and S. laticeps, from Venezuela are described and chromosome evolution in the family is discussed.

\section{Materials and Methods}

Three Prochilodontidae species were analyzed: Prochilodus mariae (21 specimens), Semaprochilodus kneri (24 specimens), and S. laticeps (7 specimens). All specimens were juveniles (immature), so sex determination was not attempted. Fish were collected with seine nets in lowland flood plains near Caicara del Orinoco, Bolivar State, Venezuela (N7³8'30", W66 $\left.09^{\circ} 00^{\prime \prime}\right)$. Voucher specimens were kept at the fish collection of Laboratório de Biologia de Peixes (Prochilodus mariae LBP 1382, Semaprochilodus kneri LBP 1384, and S. laticeps LBP 1383), Instituto de Biociências, Universidade Estadual Paulista, Botucatu, São Paulo, Brazil.

Chromosome preparations and staining techniques were conducted according to Foresti et al. (1993). Chromosome morphology was determined on the basis of arm ratio, as proposed by Levan et al. (1964), and chromosomes were classified as metacentric (M) or submetacentric (SM).

\section{Results and Discussion}

The species Prochilodus mariae exhibited $2 \mathrm{n}=54$ chromosomes, with 40 metacentric and 14 submetacentric chromosomes (Fig. 1a). The karyotype of P. mariae is very similar to those of other Prochilodus species (Pauls \& Bertollo, 1990) in terms of number of metacentric and submetacentric chromosomes.

In 21 of the specimens analyzed, the modal number of supernumerary or B chromosomes found was 0 in five animals, 1 in nine animals, 2 in six animals, and 3 in one animal (Table 1 ), resulting in a mean number of 1.143 . This value is similar to that found in a sample of $P$. lineatus collected in 1979/1980 from the natural population of the Mogi-Guaçu River that showed a B mean number equal to 1.341 (Pauls \& Bertollo, 1983). An interesting result observed in the present study was the variation in the number of B chromosomes among different cells of each fish that was $17.5 \%$ (ranging from 0.00 to $44.4 \%$ ), suggesting that these supernumerary chromosomes are mitotically unstable. A comparative study conducted with the Mogi-Guaçu River population of $P$. lineatus showed that the number of cells with $\mathrm{B}$ chromosome numbers different from the individual modal number reduced from $44.1 \%$ in 19791980 (Pauls \& Bertollo, 1983) to 0.9\% in 1987-1989 (Cavallaro et al., 2000) and 3.4\% in 1991-1992 (Oliveira et al., 1997). Oliveira et al. (1997) suggested that the variation observed in the behavior of P. lineatus B chromosomes is related to the fixation of a mitotically stable B chromosome set in the population of the Mogi-Guaçu River. Further analyses in $P$. mariae will be very helpful in the evaluation of the behavior of $\mathrm{B}$ chromosomes in this population. Another remarkable fact observed in this study was the absence of B chromosomes in only 4 animals (19\%) of the sample analyzed, showing that these supernumerary chromosomes are widespread in the population of $P$. mariae studied.

Table 1. Frequency of B chromosomes among the cells analyzed of each Prochilodus mariae specimen. Only cells with $2 \mathrm{n}=54$ chromosomes were counted.

\begin{tabular}{|c|c|c|c|c|c|c|}
\hline \multirow[t]{2}{*}{ Specimen } & \multicolumn{4}{|c|}{ Number of cells with Bs } & \multirow{2}{*}{$\begin{array}{l}\text { Modal } \\
\text { number } \\
\text { of Bs }\end{array}$} & \multirow{2}{*}{$\begin{array}{c}\text { Cells } \\
\text { counted }\end{array}$} \\
\hline & OB & $1 \mathrm{~B}$ & $2 \mathrm{~B}$ & 3B & & \\
\hline 1 & 15 & 12 & - & - & 0 & 27 \\
\hline 2 & 2 & 14 & - & - & 1 & 16 \\
\hline 3 & 3 & 6 & 19 & - & 2 & 28 \\
\hline 4 & 5 & 4 & 24 & - & 2 & 34 \\
\hline 5 & 26 & - & - & - & 0 & 26 \\
\hline 6 & 8 & 17 & - & - & 1 & 25 \\
\hline 7 & 9 & 15 & 1 & - & 1 & 25 \\
\hline 8 & 19 & - & - & - & 0 & 19 \\
\hline 9 & 2 & 15 & - & - & 1 & 17 \\
\hline 10 & 1 & 10 & - & - & 1 & 11 \\
\hline 11 & 16 & - & - & - & 0 & 16 \\
\hline 12 & 1 & 21 & - & - & 1 & 22 \\
\hline 13 & 2 & 19 & - & - & 1 & 21 \\
\hline 14 & 1 & 17 & - & - & 1 & 18 \\
\hline 15 & - & 3 & 19 & - & 2 & 22 \\
\hline 16 & 2 & 14 & - & - & 1 & 16 \\
\hline 17 & 1 & 3 & 9 & - & 2 & 13 \\
\hline 18 & 1 & 1 & 12 & - & 2 & 14 \\
\hline 19 & 19 & - & - & - & 0 & 19 \\
\hline 20 & 1 & 1 & 6 & 13 & 3 & 21 \\
\hline 21 & - & 6 & 14 & - & 2 & 20 \\
\hline
\end{tabular}

Although the presence of supernumerary chromosomes in P. lineatus, P. brevis and P. mariae might suggest the occurrence of a close relationship among these species, morphological studies have shown that this is not so (Castro $\&$ Vari, in press). Thus, it seems probable that $\mathrm{B}$ chromosomes have arisen independently in these three species. Alternatively, it may be assumed that B chromosomes were present in the ancestor of the genus and that these accessory chromosomes were lost in several species. Further data on the chromosomal constitution of other Prochilodontidae species are necessary to test these hypotheses.

A single chromosome pair with nucleolus organizer 


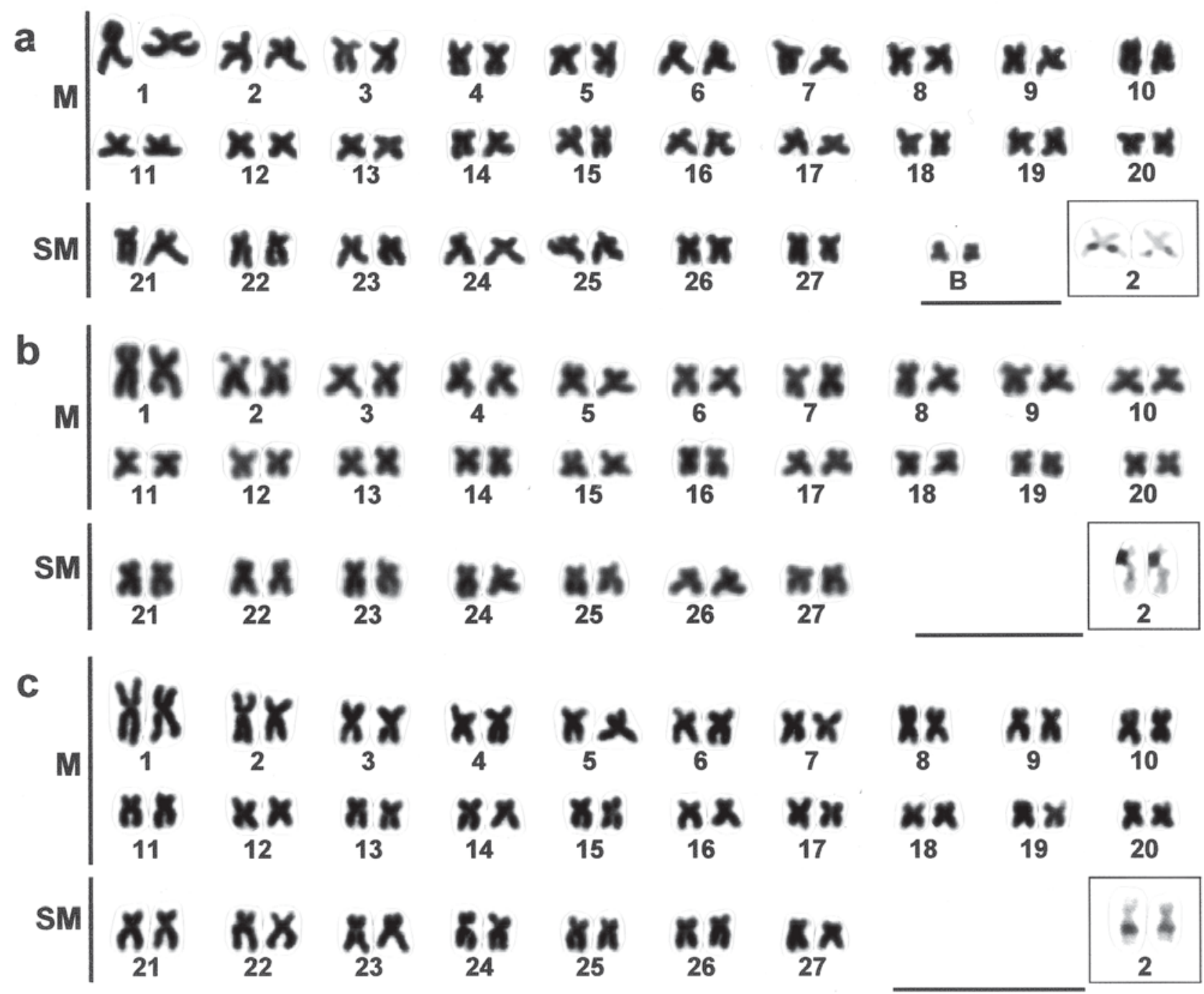

Fig. 1. Karyotypes of: a) Prochilodus mariae with 2n=54 chromosomes plus two supernumerary microchromosomes (B); b) Semaprochilodus kneri with $2 \mathrm{n}=54$ chromosomes; and c) Semaprochilodus laticeps with $2 \mathrm{n}=54$ chromosomes. In the insets, silver stained chromosomes with the nucleolus organizer regions in pair 2 . Bars $=10 \mu \mathrm{m}$.

regions (NORs), probably pair 2, was found after silver staining (Ag-NORs) in P. mariae (Fig. 1a). The same was reported to occur in other Prochilodus species (Pauls \& Bertollo, 1990), showing that this characteristic is very much conserved in the genus. The remarkable conservatism of the Ag-NOR-bearing chromosome pair in Prochilodus species is noteworthy considering that even the species of Curimatidae (Vênere \& Galetti, 1989; Feldberg et al., 1992; Oliveira \& Foresti, 1993; Navarrete \& Júlio, 1997) and Anostomidae (Galetti Jr et al., 1991a, 1991b; Galetti Jr et al., 1995) that have very conservative karyotypes, usually display speciesspecific Ag-NOR-bearing chromosomes.

The karyotype of $P$. mariae showed a large amount of heterochromatin, basically in the centromeric and pericentromeric regions of almost all chromosomes (Fig. 2a) as observed in P. lineatus (Pauls \& Bertollo, 1990). Additionally, the long arm of pair 5 was entirely heterochromatic (Fig. 2a) as observed in P. lineatus (Maistro et al., 2000). The supernumerary chromosomes of $P$. mariae were entirely heterochromatic (Fig. 2a) as observed in $P$. lineatus B chromosomes (Pauls \& Bertollo, 1990; Maistro et al., 2000; Jesus et al., 2003).

The species Semaprochilodus kneri and S. laticeps exhibited $2 n=54$ chromosomes, with 40 metacentric and 14 submetacentric chromosomes (Figs. 1b and 1c, respectively). Cytogenetic studies conducted by Feldberg et al. (1987) showed that $S$. insignis and $S$. taeniurus also have $2 \mathrm{n}=54$ meta-submetacentric chromosomes. The only difference found between $S$. insignis and $S$. taeniurus was the presence of a putative ZZ/ZW sex chromosome system in $S$. taeniurus 


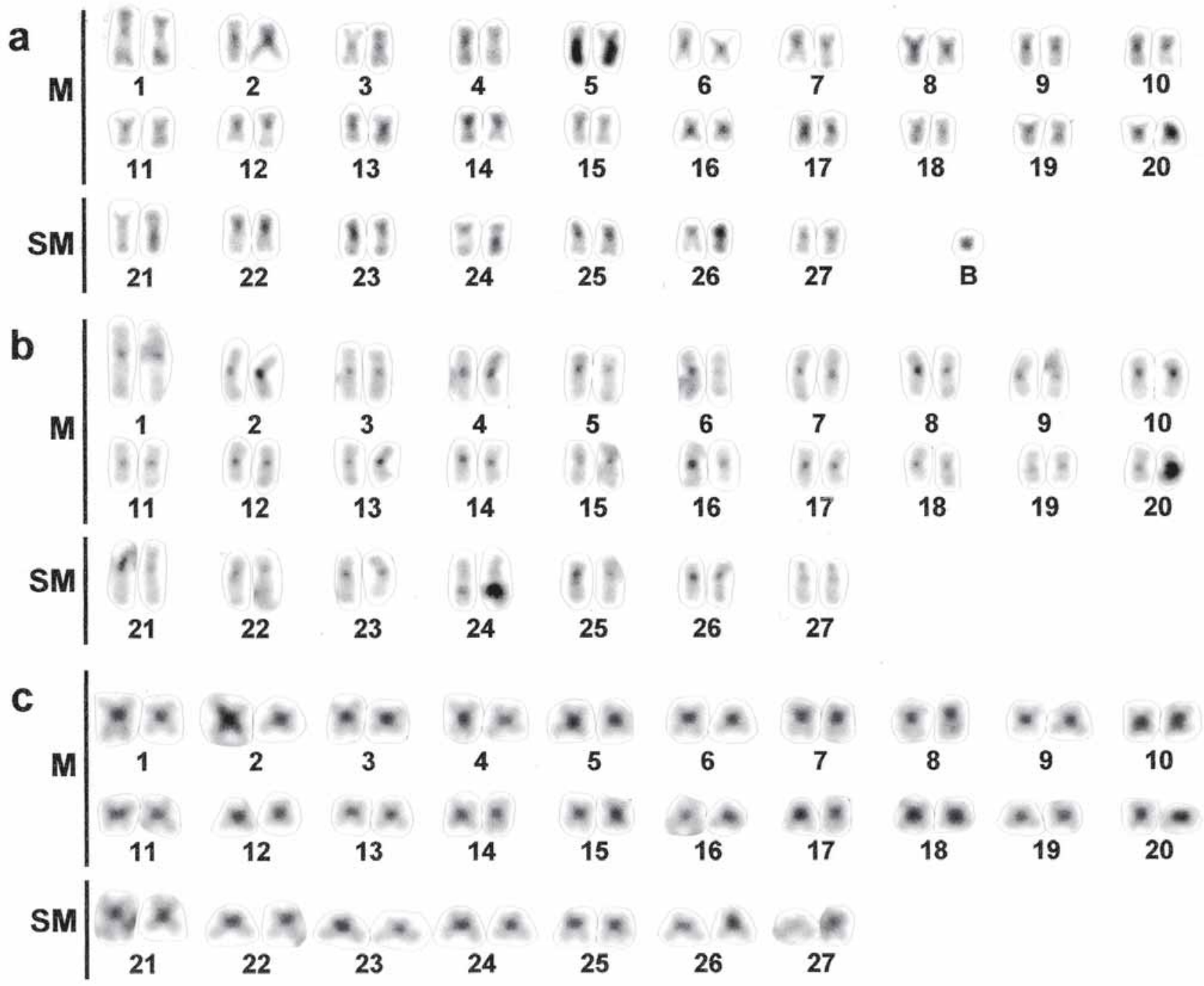

Fig. 2. Karyotypes treated with the C-banding technique. a) Prochilodus mariae - "B" indicates a supernumerary microchromosome; b) Semaprochilodus kneri; and c) Semaprochilodus laticeps.

(Feldberg et al., 1987). The analyses of several metaphases of $S$. laticeps showed that, in some cells, the first chromosome pair was composed of two chromosomes with a small difference in size. Considering that in the present study the sex of the fish analyzed could not be precisely confirmed, these size differences and the presence of sex chromosomes in this species cannot be herein positively correlated.

In $S$. kneri and $S$. laticeps, pair 2 chromosomes clearly exhibited secondary constrictions in several metaphases corresponding to the Ag-NOR-bearing chromosomes (Figs. $1 \mathrm{~b}$ and 1c, respectively). Both Ag-NOR-bearing chromosomes were frequently observed to associate in several $S$. kneri metaphases, which explains the occurrence of interphasic cells with one $(62,5 \%)$ or two nucleolus $(37,5 \%)$. Although all Prochilodus species exhibit NORs in the long arm of the second chromosome pair (Pauls \& Bertollo, 1990; present paper), studies conducted by Feldberg et al. (1987) showed that S. insignis and S. taeniurus displayed interstitial Ag-
NORs in the short arm of a large submetacentric pair as observed in the present study in S. kneri (Fig. 1b). The presence of Ag-NORs in the long arm of the second chromosome pair in S. laticeps may indicate the presence of a possible ancestral condition or the occurrence of a second event of pericentric inversion in the Ag-NOR-bearing chromosomes of this species.

The karyotype of $S$. kneri and S. laticeps displayed a large amount of heterochromatin, mainly in the centromeric and pericentromeric regions of almost all chromosomes (Figs. $2 \mathrm{~b}$ and $2 \mathrm{c}$ ). An interstitial heterochromatic segment observed in the long arm of $S$. kneri chromosome pair 24 was not observed in the karyotype of S. laticeps. The C-banding of $S$. insignis and $S$. taeniurus was also characterized by the presence of large C-positive bands pericentromerically positioned in all chromosomes (Feldberg et al., 1987). The data available show that heterochromatin distribution is also very conservative in Prochilodontidae species. 
The analysis of the nucleolus organizer regions in the Prochilodontidae species herein studied showed the occurrence of polymorphisms in the Ag-NOR-bearing chromosomes of the three species, more evidently in $P$. mariae (Fig. 1a) and S. laticeps (Fig. 1c). This type of NOR size polymorphism was described in several Prochilodus species (Pauls \& Bertollo, 1990) and is very common among fish (Almeida-Toledo \& Foresti, 1985).

Our data confirm the conservative nature of the chromosome number and morphology of Prochilodontidae and reinforce the idea that small structural chromosome rearrangements may be the main cause of karyotypic diversification in this group (Pauls \& Bertollo, 1990). The presence of $2 n=54$ biarmed chromosomes have also been consistently found in the families Anostomidae (Galetti Jr et al., 1991a, 1991b; Galetti Jr et al., 1995), Curimatidae (Vênere \& Galetti, 1989; Feldberg et al., 1992; Oliveira \& Foresti, 1993; Navarrete \& Júlio, 1997), and Chilodontidae (Cestari et al., 1990; Vênere, 1998), corroborating the hypothesis that these four families constitute a natural group in the order Characiformes (Vari, 1983).

On the other hand, small differences in chromosome morphology and Ag-NOR positioning have been observed in the karyotypes of the Prochilodontidae species, suggesting that chromosome rearrangements that do not change the number or the morphology of the chromosomes, such as paracentric inversions, may have occurred during the evolutionary process of the species, as suggested by Feldberg et al. (1987).

\section{Acknowledgments}

The authors are grateful to Ricardo M. C. Castro for the taxonomic identification of the species. Funds supporting this study were provided by Consejo de Investigación-UDO, FAPESP and CNPq.

\section{Literature Cited}

Almeida-Toledo, L. F. \& F. Foresti F. 1985. As regiões organizadoras do nucléolo em peixes. Ciência e Cultura, 37: 448-453.

Castro R. M. C. \& R. P. Vari. in press. Detritivores of the South American family Prochilodontidae (Teleostei: Ostariphysi: Characiformes): a phylogenetic and revisionary study. Smithsonian Contributions to Zoology.

Cavallaro, Z. I., L. A. C. Bertollo, F. Perfectti \& J. P. M. Camacho. 2000. Frequency increase and mitotic stabilization of a B chromosome in the fish Prochilodus lineatus. Chromosome Research, 8: 627-634.

Cestari, M. M., R. Ferreira \& P. M. Galetti Jr. 1990. Complemento cariotípico de duas espécies de peixes ornamentais: Chilodus punctatus (Chilodontidae) e Anostomous anostomus (Anostomidae) (Characiformes). Resumos do III Simpósio de Citogenética Evolutiva e Aplicada de Peixes Neotropicais, pp. 3.
Dias, A. L., F. Foresti \& C. Oliveira. 1998. Synapsis in supernumerary chromosomes of Prochilodus lineatus (Teleostei: Prochilodontidae). Caryologia, 51: 105113.

Feldberg, E., L. A. C. Bertollo, L. F. Almeida-Toledo, F. Foresti, O. Moreira-Filho \& A. F. Santos. 1987. Biological aspects of Amazonian fishes. IX. Cytogenetic studies in two species of the genus Semaprochilodus (Pisces, Prochilodontidae). Genome, 29: 1-4.

Feldberg, E., J. I. R. Porto \& L. A. C. Bertollo. 1992. Karyotype evolution in Curimatidae (Teleostei, Characiformes) of the Amazon region. I. Studies on the genera Curimata, Psectrogaster, Steindachnerina and Curimatella. Revista Brasileira de Genética, 15: 369-383.

Foresti, F., C. Oliveira \& L. F. Almeida-Toledo. 1993. A method for chromosome preparations from large specimens of fishes using in vitro short treatment with colchicine. Experientia, 49: 810-813.

Galetti Jr, P. M., A. C. G. Cesar \& P. C. Vênere. 1991a. Heterochromatin and NORs variability in Leporinus fish (Anostomidae, Characiformes). Caryologia, 44: 287-292.

Galetti Jr, P. M., C. A. Mestriner, P. C. Vênere \& F. Foresti. 1991b. Heterochromatin and karyotypic reorganization in fish of the family Anostomidae (Characiformes). Cytogenetics and Cell Genetics, 56: 116-121.

Galetti Jr, P. M., N. R. W. Lima \& P. C. Vênere. 1995. A monophyletic ZW sex chromosome system in Leporinus (Anostomidae, Characiformes). Cytologia, 60: 375-382.

Goulding, M. 1981. Man and fisheries on an Amazon frontier. Kluwer Academic Publishers. 137p.

Jesus, C. M., P. M. Galetti Jr, S. R. Valentini \& O. MoreiraFilho. 2003. Molecular characterization and chromosomal location of two families of satellite DNA in Prochilodus lineatus (Pisces, Prochilodontidae), a species with B chromosomes. Genetica, 118: 25-32.

Levan, A., A. Fredga \& A. Sandburg. 1964. Nomenclature for centromeric position on chromosomes. Hereditas, 52: 201220.

Lowe-McConell, R. 1975. Fish communities in tropical freshwaters. New York, Longman Publishing. 337p.

Maistro, E. L., C. Oliveira \& F. Foresti. 2000. Cytogenetic analysis of A- and B-chromosomes of Prochilodus lineatus (Teleostei, Prochilodontidae) using different restriction enzyme banding and staining methods. Genetica, 108: 119-125.

Navarrete, M. C. \& H. F. Júlio Jr. 1997. Cytogenetic analysis of four curimatids from the Paraguay Basin, Brazil (Pisces: Characiformes: Curimatidae). Cytologia, 62: 241-247.

Oliveira, C. \& F. Foresti. 1993. Occurrence of supernumerary microchromosomes in Steindachnerina insculpta (Pisces, Characiformes, Curimatidae). Cytobios, 76:183-186.

Oliveira, C., S. M. R. Saboya, F. Foresti, J. A. Senhorini \& G. Bernardino. 1997. Increased B chromosome frequency and absence of drive in the fish Prochilodus lineatus. Heredity, 79: 473-476. 
Pauls, E. \& L. A. C. Bertollo. 1983. Evidence for a system of supernumerary chromosomes in Prochilodus scrofa Steidachner, 1881 (Pisces, Prochilodontidae). Caryologia, 36:307-314.

Pauls, E. \& L. A. C. Bertollo. 1990. Distribution of a supernumerary chromosome system and aspects of karyotypic evolution in the genus Prochilodus (Pisces, Prochilodontidae). Genetica, 81:117-123.

Vari, R. P. 1983. Phylogenetic relationships of the families Curimatidae, Prochilodontidae, Anostomidae and Chilodontidae (Pisces, Characiformes). Smithsonian Contributions to Zoology, 378: 1-60.
Vênere, P.C. 1998. Diversificação cariotípica em peixes do médio rio Araguaia, com ênfase em Characiformes e Siluriformes (Teleostei, Ostariophysi). Unpublished Ph. D. Dissertation, Universidade Federal de São Carlos, São Carlos. 130p.

Vênere, P. C. \& P. M. Galetti Jr. 1989. Chromosome evolution and phylogenetic relationships of some Neotropical Characiformes of the family Curimatidae. Revista Brasileira de Genética, 12: 17-25.

Received July 22, 2003

Accepted September 26, 2003 